\title{
Response of cowpea (Vigna anguiculata [L.] walp) varieties following application of nitrogen fertilizers and inoculation
}

\author{
Abe Miheretu ${ }^{1}$ and Joseph Sarkodie-Addo ${ }^{2}$ \\ ${ }^{1,2}$ (Department of Soil and Crop and Sciences, College of Agriculture and Natural Resources, Kwame Nkrumah \\ University of Science and Technology, Ghana)
}

\begin{abstract}
Cowpea (Vigna anguiculata [L.] Walp) plays a significant role in contributing to food security and agricultural sustainability in less developed countries like Ghana, Nigeria, Zambia and several others in subSaharan Africa. However, in Ghana the yield of cowpea is among the lowest in the world. This situation is attributed to the exposure of soil to wind and water erosion there by depleting macro-nutrients such as Nitrogen, Phosphorus and Potassium estimated 40-60 $\mathrm{kg} \mathrm{ha}^{-1}$ per year, which is among the highest in Africa. To this end, field experiment was conducted to determine the growth and yield response of two cowpea varieties to application of nitrogen from organic and inorganic sources and rhizobia inoculant in semi deciduous forest vegetation zone of Ghana during the major rainy season of 2016. Poultry manure was applied as organic source, while urea was applied as inorganic source of nitrogen in single and combination of organic and inorganic. The experimental design used in the study was a $2 \times 7$ factorial arranged in RCBD with four replications. The maximum leaf area index (0.999), crop growth rate $\left(11.89 \mathrm{~g} \mathrm{~m}^{-2}\right.$ day $\left.^{-1}\right)$ and grain yield $\left(2005.50 \mathrm{~kg} \mathrm{ha}{ }^{-1}\right)$ of cowpea varieties were obtained by combined application of poultry manure at the rate of 1 ton $\mathrm{ha}^{-1}$ and inorganic nitrogen fertilizer at the rate of $10 \mathrm{~kg} \mathrm{~N} \mathrm{ha}^{-1}$. Therefore, the study revealed that combined application of poultry manure at the rate of 1 ton hal and inorganic nitrogen fertilizer at the rate of $10 \mathrm{~kg} \mathrm{~N} \mathrm{ha}$ ${ }^{I}$ were significantly increased the growth, grain yield and yield components of cowpea varieties.
\end{abstract}

Keywords: Cowpea, Organic source, Poultry manure, Rhizobia inoculant, Urea.

\section{Introduction}

Cowpea is one of the major crops very important to the livelihood of millions of relatively poor people in less developed countries of tropics. It is an important food crop in sub-Saharan Africa, mainly in the dry savannah regions of West Africa. The seeds of cowpea are a major source of plant proteins and vitamins, feed for animals and also as source of cash income. It is also a major component of tropical farm system due to its capability to improve unfertile soils through Nitrogen fixation and as a cover crop [1]. Cowpea plays a role to contribute substantially to human and animal's health, food security and Agricultural sustainability for less developed countries like Ghana, Nigeria, Zambia and several others in sub-Saharan Africa [2]. In Ghana cowpea is the second most important legume crop and second to groundnut in total area coverage and annual production [3]. Ghana produces 143,000 metric tons of cowpea annually on about 156,000 ha of land making it the fifth highest producer in Africa [3]. Cowpea is an important crop in Ghana due to its contribution to national GDP, income of the farmers, food and nutrition security [4]. However, the grain yield of cowpea in Ghana is among the lowest in the world, averaging $310 \mathrm{~kg} \mathrm{ha}^{-1}$ [5]. To overcome the problem raised many efforts have been made to improve cowpea productivity in Ghana through various ways including the introduction of new varieties. However, the improved varieties alone could not achieve the optimum yield which is sustainable.

In Ghana, low soil fertility is attributed to bush fires which usually occur annually during the dry season commencing from October to April the following year [6]. This situation renders the soil bare exposing it to wind and water erosion in the dry and rainy seasons respectively thereby depleting macro-nutrients such as nitrogen, phosphorus and potassium and organic matter from the soil [7]. The depletion rate of nitrogen, phosphorus and potassium in the country ranges from $40-60 \mathrm{~kg} \mathrm{ha}^{-1}$ per year, which is among the highest in Africa [8]. Moreover, it is reported by MoFA [9] that in Ghana annually a depletion rate of $30 \mathrm{~kg} \mathrm{ha}^{-1}$ of nitrogen, $3 \mathrm{~kg} \mathrm{ha}^{-1}$ phosphorus and $17 \mathrm{~kg} \mathrm{ha}^{-1}$ of potassium were recorded for the period of 1982-1984 and the projected figure for year 2000 were $35 \mathrm{~kg} \mathrm{ha}^{-1}$ of nitrogen, $4 \mathrm{~kg} \mathrm{ha}^{-1}$ of phosphorus and $14 \mathrm{~kg} \mathrm{ha}^{-1}$ of potassium. This indicates that the fertility of the soil in the country declines through time that negatively affects the agricultural productivity. However, most of the farmers in Ghana do not apply fertilizer to cowpea since they perceive that cowpea does not require fertilizer [10]. Furthermore, there is a limitation in using fertilizers for agricultural production in Ghana, even by Africa standards that is less than $8 \mathrm{~kg} \mathrm{ha}^{-1}$ on average in contrast to the Abuja declaration target of $50 \mathrm{~kg} \mathrm{ha}^{-1}$ [9]. As in other regions in Africa, local farmers use insufficient nutrient input, inappropriate quality and inefficient combination of fertilizers that resulted in less productivity [11]. Therefore, this trend results in a deeply unbalanced soil nutrient composition that eventually leads to a reduction in a crop growth and yield potential. Hence it is important that an integrated plant nutrient 
management should be practiced for balanced soil nutrient that resulted in sustainable cowpea yield and soil fertility as well.

Research indicated that organic manure will lose approximately one-third of mineral fertilizer requirement and improve soil organic matter content over a longer period [12]. Furthermore, inoculation of legumes by commercially prepared inoculants contributes to improvement in effective nodulation of the legumes, symbiotic nitrogen fixation and plant grain yield [13]. Though it is widely agreed that an application of organic manure in combination with mineral fertilizer for crop is more beneficial for sustainable crop production and soil fertility, there is a limited research in the country on response of cowpea to an application of organic manure, inorganic nitrogen fertilizers, their integration and rhizobia inoculation. Therefore, this study was conducted with the objective of determining the effect on the growth and yield of cowpea varieties following application of poultry manure and inorganic nitrogen fertilizer and rhizobia inoculation.

\subsection{Experimental area}

\section{Materials And Methods}

The field experiment were conducted during the major cropping season of June, 2016 at the Plantation Section of the Crop and Soil Sciences Department, Kwame Nkrumah University of Science and Technology (KNUST), Kumasi $\left(06^{0} 43^{\prime} \mathrm{N}, 01^{0} 33^{\prime \prime} \mathrm{W}\right)$ which falls in the semi deciduous forest vegetation zone of Ghana. The area is described with a bimodal rainfall pattern with an average annual rainfall of $1422.4 \mathrm{~mm}$ with the major rainy season that extends from mid-March to July and the minor rainy season that extends from September to October.

\subsection{Soil characteristics}

The soil samples that collected from the field at the depth of $0-15 \mathrm{~cm}$ were air dried, grounded with mortar pestle and sieved in $2 \mathrm{~mm}$ sized mesh in the soil laboratory. The soil textural class was sandy loam with sand $(84.3 \%)$, silt $(3.90 \%)$ and clay $(11.80 \%)$. The soil $\mathrm{pH}$ was 5.94 . The soil contained total $\mathrm{N}(0.06 \%)$, available P (6.39 mg kg$\left.{ }^{-1}\right)$, Organic C (1.04\%), exchangeable bases $\mathrm{K}\left(0.01 \mathrm{cmol} \mathrm{kg}^{-1}\right), \mathrm{Ca}\left(4.08 \mathrm{cmol} \mathrm{kg}^{-1}\right)$ and $\mathrm{Mg}\left(1.00 \mathrm{cmol} \mathrm{kg}^{-1}\right)$ and micro nutrients $\mathrm{Fe}\left(3.01 \mathrm{mg} \mathrm{kg}^{-1}\right)$ and $\mathrm{Zn}\left(1.29 \mathrm{mg} \mathrm{kg}^{-1}\right)$.

\subsection{Poultry manure characteristics}

The poultry manure samples were air dried and ground manure samples were sieved through $2 \mathrm{~mm}$ sieve and ignited over a temperature of $500^{\circ} \mathrm{C}$ for two hours and the ash was extracted by using HCL [14], [15]. The poultry manure $\mathrm{pH}$ was 8.4 . The poultry manure contained total $\mathrm{N}(3.06 \%)$, available $\mathrm{P}(0.94 \%)$, Organic $\mathrm{C}$ (36.63\%), exchangeable bases $\mathrm{K}(3.59 \%), \mathrm{Ca}(9.91 \%)$ and $\mathrm{Mg}(6.75 \%)$ and micro nutrients Fe $\left(477.50 \mathrm{mg} \mathrm{kg}^{-1}\right)$, Zn $\left(277.07 \mathrm{mg} \mathrm{kg}^{-1}\right)$ and $\mathrm{Mn}\left(437.30 \mathrm{mg} \mathrm{kg}^{-1}\right)$.

\subsection{Experimental Design and treatments}

Two factors, cowpea varieties and fertilizer levels were studied. Asontem and Songotra cowpea varieties were used. The inorganic source of $\mathrm{N}$ was urea $(46 \% \mathrm{~N})$, while the organic source of $\mathrm{N}$ was poultry manure. The fertilizer levels were $0 \mathrm{~kg} \mathrm{~N} \mathrm{ha}^{-1}$ (Control), $20 \mathrm{~kg} \mathrm{~N} \mathrm{ha}^{-1}, 40 \mathrm{~kg} \mathrm{~N} \mathrm{ha}^{-1}, 2$ ton poultry manure ha ${ }^{-1}, 1$ ton poultry manure $\mathrm{ha}^{-1}+10 \mathrm{~kg} \mathrm{~N} \mathrm{ha}^{-1}, 1$ ton poultry manure ha $\mathrm{ha}^{-1}+20 \mathrm{~kg} \mathrm{~N} \mathrm{ha}^{-1}$ and inoculant (BR 3262 rhizobium strain) $5 \mathrm{~g} \mathrm{~kg}^{-1}$ of seed. The experimental design was a 2 x 7 factorial arranged in randomized complete block (RCBD) with four replications. There were 56 plots each measuring an area of $6 \mathrm{~m}^{2}$.

\subsection{Planting and fertilizer application}

The seeds were planted at the planting depth of $4-5 \mathrm{~cm}$ with the spacing of $20 \mathrm{~cm}$ between the plants and $60 \mathrm{~cm}$ between the rows at 3 seeds per hill that were thinned to 2 plants per hill on 14 days after planting, corresponding to a population density of 166,667 plants ha $^{-1}$. Poultry manure was applied and worked out with the soil 6 days before planting the cowpea. The inoculant containing strain BR 3262 was applied to the seeds at the time of planting at the rate of $5 \mathrm{~g} \mathrm{~kg}^{-1}$ of seed. Urea $(46 \% \mathrm{~N})$ fertilizer was applied 14 days after planting the cowpea and all plots were treated with $40 \mathrm{~kg} \mathrm{P}_{2} \mathrm{O}_{5} \mathrm{ha}^{-1}$ by using triple superphosphate $\left(46 \% \mathrm{P}_{2} \mathrm{O}_{5}\right)$.

\subsection{Data Collection}

Plant height, number of primary branches and number of leaves were measured on 30, 45 and 60 days after planting and number of seeds per pod, 100 seed weight and grain yield were recorded at harvest.

\subsubsection{Leaf area index (LAI)}

Leaf area index was calculated by the method described by Shortall and Liebhardt [16]. 


$$
L A I=\frac{(Y \times N \times A L)}{A P}
$$

Where, $\mathrm{Y}=$ population of plants per plot, $\mathrm{N}=$ average number of leaves, $\mathrm{AL}=$ average area per leaf and $\mathrm{AP}=$ area of plot.

\subsubsection{Crop growth rate (CGR)}

Crop growth rate was determined from the total dry weight at the sampling periods of 30 and 45 DAP. It was calculated by using the formula set by Radford [17].

$$
C G R=\frac{W 2-W 1}{T 2-T 1}\left(g^{-2} d a y^{-1}\right)
$$

Where, W2 and W1 were the total dry weight (above ground) during the sampling periods and $\mathrm{T} 2$ and $\mathrm{T} 1$ were the sampling periods for the total dry weight.

\subsubsection{Harvest Index (HI)}

The harvest index was determined by the formula set by Donald [18] and expressed in a percentage bases.

$$
H I=\frac{\text { Economic yield }}{\text { Total biological yield (above ground) }} \times 100
$$

Where, Economic yield is a grain yield and the total biological yield is the summation of total biomass and grain yield plus pod chaff.

\subsection{Data analysis}

All data collected were subjected to Analysis of Variance (ANOVA) using the software GenStat statistical package (Version 12). The treatment means were separated using the Least Significant Difference (LSD) at $5 \%$ level of probability.

\subsection{Effect on plant height}

\section{Results And Discussions}

The highest plant height was recorded by sole application of inorganic nitrogen fertilizer at the rate of $20 \mathrm{~kg} \mathrm{~N} \mathrm{ha}^{-1}$ and poultry manure at the rate of 2 ton ha ${ }^{-1}$, whereas the lowest was recorded from the control plot (Table 1). This might be due to the maximum plant growth that took place on 60 DAP. This result is in line with the report of Agyeman et al. [19] who reported that at the final harvest stage plant height for cowpea were consistently increased. Similarly, Blum et al. [20] suggested that the final height of the plant can be taken as a vital measure of the response of plants to nutrient and moisture stress. The responsiveness of cowpea to lower rate of nitrogen in the present study might be due to the ability of the cowpea that can fix nitrogen to satisfy its nitrogen requirement. This result is in line with the result of Dart et al. [21] who suggested that an application of a starter nitrogen at the rate of $20 \mathrm{~kg} \mathrm{~N} \mathrm{ha}^{-1}$ is beneficial for an improvement of the vegetative growth of cowpea. Verma et al. [22] confirmed that cowpea responds to small quantity of nitrogen fertilizer applied as a starter dose. Furthermore, the result of present work showed that sole application of poultry manure at the rate of 2 ton ha ${ }^{-1}$ gave the highest plant height on 60 DAP. This might be due to the fact that an application of organic manure contributes to an improvement in soil fertility and various soil properties like moisture holding capacity, infiltration rate of the soil and addition of semi decomposed organic matter that contributes to the growth of the plants [23], [24]. In vein with this, Blum et al. [20] and Kisetu and Assenga [25] obtained the maximum height of cowpea on sixth week after planting from the plots treated with poultry manure at the rate of 2 ton $\mathrm{ha}^{-1}$ and the minimum from control plots. Plant height was significantly affected by cowpea variety at all the sampling periods. Asontem plants were consistently taller than Songotra at all the sampling periods. The variation in plant height could be attributed to the genetic effect of each variety. This result is in line with the finding of Karikari et al. [26] who noted that plant height was significantly affected by cowpea variety.

\subsection{Effect on number of primary branches}

The greatest numbers of primary branches per plant were produced from the combined application of poultry manure at the rate of 1 ton ha ${ }^{-1}$ and inorganic nitrogen fertilizer at the rate of $10 \mathrm{~kg} \mathrm{~N} \mathrm{ha}{ }^{-1}$, while the lowest was produced from the control plot and inoculant treatment on 60 DAP (Table 1). This could be due to an improvement in soil fertility as a result of the presence of adequate quantity of organic matter and micro nutrients in the poultry manure that were used for the experiment. This finding is in agreement with the investigation of Olusegun[27] who found that combined application of organic manure and inorganic nitrogen fertilizer resulted in greater number of branches of cowpea as compared to sole application of either organic 
manure or inorganic nitrogen fertilizer. Furthermore, the number of branches per plant was significantly different among the cowpea varieties at 30 and 45 DAP. The Asontem produced more number of primary branches per plant than Songotra variety. This variation might be due to the differences in genetic composition among the cowpea varieties. This finding is in line with the investigation of Agyeman et al. [19] and Amoatey [28] who reported that there were significant differences in number of branches per plant among different cowpea varieties.

Table 1. Effect of treatments on plant height and number of primary branches.

\begin{tabular}{|c|c|c|c|c|c|c|}
\hline & \multicolumn{3}{|c|}{ Plant height $(\mathrm{cm})$} & \multicolumn{3}{|c|}{ Number of primary branches } \\
\hline Treatments & 30 DAP & 45 DAP & 60 DAP & 30 DAP & 45 DAP & 60 DAP \\
\hline \multicolumn{7}{|l|}{ Varieties } \\
\hline Asontem & 20.03 & 30.47 & 77.01 & 2.11 & 2.29 & 2.68 \\
\hline Songotra & 16.04 & 24.96 & 62.17 & 0.61 & 1.64 & 2.89 \\
\hline LSD (5\%) & 1.16 & 2.23 & 2.23 & 0.21 & 0.16 & NS \\
\hline \multicolumn{7}{|l|}{ Fertilizer levels } \\
\hline $0 \mathrm{~kg} \mathrm{~N} \mathrm{ha}^{-1}$ & 16.6 & 27.18 & 64.82 & 0.88 & 1.50 & 2.13 \\
\hline $20 \mathrm{~kg} \mathrm{~N} \mathrm{ha}^{-1}$ & 18.85 & 28.03 & 71.82 & 1.25 & 2.25 & 3.00 \\
\hline $40 \mathrm{~kg} \mathrm{~N} \mathrm{ha}^{-1}$ & 18.08 & 27.45 & 70.52 & 1.25 & 1.88 & 3.00 \\
\hline 2 ton $\mathrm{PM} \mathrm{ha}^{-1}$ & 18.68 & 28.18 & 72.05 & 1.88 & 2.25 & 3.13 \\
\hline 1 ton $\mathrm{PM} \mathrm{ha}^{-1}+10 \mathrm{~kg} \mathrm{~N} \mathrm{ha}^{-1}$ & 18.15 & 27.07 & 69.42 & 1.62 & 2.62 & 3.25 \\
\hline 1 ton $\mathrm{PM} \mathrm{ha}^{-1}+20 \mathrm{~kg} \mathrm{~N} \mathrm{ha}^{-1}$ & 16.75 & 27.60 & 68.10 & 1.38 & 1.75 & 2.88 \\
\hline Inoculant & 19.18 & 28.50 & 70.37 & 1.25 & 1.50 & 2.13 \\
\hline LSD (5\%) & NS & NS & 4.18 & NS & NS & 0.20 \\
\hline \multicolumn{7}{|l|}{ Variety X Fertilizer level } \\
\hline LSD (5\%) & NS & NS & NS & NS & NS & NS \\
\hline $\mathrm{CV}(\%)$ & 11.9 & 14.9 & 5.9 & 29.6 & 19.2 & 10.9 \\
\hline
\end{tabular}

$\mathrm{DAP}=$ Days after planting. NS= Not significant. $\mathrm{PM}=$ Poultry manure.

\subsection{Effect on number of leaves}

The maximum number of leaves per plant were recorded in the combined application of poultry manure at the rate of 1 ton $\mathrm{ha}^{-1}$ and inorganic nitrogen fertilizer at the rate of $10 \mathrm{~kg} \mathrm{~N} \mathrm{ha}^{-1}$, whereas the minimum number of leaves per plant were recorded by the application of inoculant only (Table 2). This might be due to the slow but consistent release of plant nutrients from poultry manure aided by inorganic nitrogen fertilizer that could have helped the soil microorganisms in the faster decomposition of the poultry manure which leads to the availability of plant nutrients. This result is in agreement with the work of Olusegun [27] who reported that combined application of pig manure with inorganic nitrogen fertilizer were resulted in greatest number of leaves per plant than sole application of manure, inorganic nitrogen fertilizer and control plots. Also significant differences in number of leaves per plant were observed among the cowpea varieties. The Asontem variety effect was greater than Songotra variety. This might be due to the genetic potential of Asontem variety to produce more branches which probably resulted in the greater production of leaves. This result is in conformity with the investigation of earlier workers who observed significant difference in number of leaves per plant among different cowpea varieties [29].

\subsection{Effect on leaf area index (LAI)}

The greatest leaf area index was recorded by combined application of poultry manure at the rate of 1 ton $\mathrm{ha}^{-1}$ and inorganic nitrogen fertilizer at the rate of $10 \mathrm{~kg} \mathrm{~N} \mathrm{ha}^{-1}$, while the lowest was recorded by inoculant plot (Table 2). This might be due to the production of more number of leaves at the same period with the same level of fertilizer application as discussed above. This result implies that combined application of inorganic nitrogen fertilizer and poultry manure could contribute to the significant increase in leaf area index which indicates synthetically active regions on a leaf for interception of solar radiation necessary during the process of photosynthesis. Boateng et al. [30] reported that leaf area index of maize crop was significantly increased by combined application of poultry manure and inorganic nitrogen fertilizer. Varietal differences in leaf area index were significant on both days; with Asontem producing the greater at 45 DAP while Songotra produced the greater at 60 DAP. This result is in line the findings of earlier workers who reported that the mean leaf area index was significantly differed among cowpea varieties in the third sampling stage [31]. Variation in time of leaf are index also supports the findings Addo-Quaye et al. [31] that in some varieties the leaf area index increased with time, while for others it reduced or remains the same. The variations in leaf area index among the cowpea varieties might be due to the genetic compositions that attributed to variations in growth stages and number of leaves produced. It was suggested by Addo-Quaye et al. [31] that for optimum yield of cowpea to be achieved, leaf area index between 1 and 2 is required after flowering, which was found in the present study. 


\subsection{Effect on crop growth rate (CGR)}

The maximum CGR was recorded by combined application of poultry manure at the rate of 1 ton ha ${ }^{-1}$ and inorganic nitrogen fertilizer at the rate of $10 \mathrm{~kg} \mathrm{~N}^{-1}{ }^{-1}$, while the minimum was recorded from the control and inoculant treatments (Table 2). This could be due to an improvement in soil organic matter and nutrient availability which resulted in an improvement in soil fertility that led to an improvement in plant growth. Olusegun [27] observed that combined application of organic manure and inorganic nitrogen fertilizer to cowpea resulted in a significant increase in plant growth and development than single application of organic manure and inorganic nitrogen fertilizer. Significant differences in CGR were not recorded among the two cowpea varieties, which contradicts that of Karikari et al. [26] who observed significant differences in crop growth rate among two cowpea varieties. In all the growth parameters in the present study no significant effects were observed among the interaction of cowpea varieties and different levels of fertilizer, which agrees with other reports [32], [33], although Abayomi et al. [34] found a significant interaction between cowpea genotype and fertilizer levels.

Table 2. Effect of treatments on number of leaves, leaf area index and CGR.

\begin{tabular}{|c|c|c|c|c|c|c|c|}
\hline & \multicolumn{3}{|c|}{ Number of leaves } & \multicolumn{3}{|c|}{ Leaf area index } & \multirow[b]{2}{*}{$\begin{array}{c}\text { CGR } \\
\left(\mathrm{g} \mathrm{m}^{-2} \mathrm{day}^{-1}\right.\end{array}$} \\
\hline Treatments & $\begin{array}{c}\text { 30 } \\
\text { DAP }\end{array}$ & $\begin{array}{c}45 \\
\text { DAP }\end{array}$ & $\begin{array}{c}\text { 60 } \\
\text { DAP }\end{array}$ & $\begin{array}{c}30 \\
\text { DAP }\end{array}$ & $\begin{array}{c}45 \\
\text { DAP }\end{array}$ & $\begin{array}{c}\text { 60 } \\
\text { DAP }\end{array}$ & \\
\hline \multicolumn{8}{|l|}{ Varieties } \\
\hline$\overline{\text { Asontem }}$ & 8.93 & 17.54 & 22.43 & 0.384 & 0.876 & 1.149 & 8.65 \\
\hline Songotra & 7.00 & 13.93 & 21.46 & 0.328 & 0.748 & 1.472 & 8.18 \\
\hline $\operatorname{LSD}(5 \%)$ & 0.16 & 0.22 & NS & NS & 0.049 & 0.082 & NS \\
\hline \multicolumn{8}{|l|}{ Fertilizer levels } \\
\hline $0 \mathrm{~kg} \mathrm{~N} \mathrm{ha}^{-1}$ & 7.12 & 14.38 & 20.50 & 0.304 & 0.696 & 1.164 & 7.01 \\
\hline $20 \mathrm{~kg} \mathrm{~N} \mathrm{ha}^{-1}$ & 8.12 & 17.12 & 23.88 & 0.401 & 0.942 & 1.459 & 9.20 \\
\hline $40 \mathrm{~kg} \mathrm{~N} \mathrm{ha}^{-1}$ & 7.75 & 14.88 & 19.88 & 0.354 & 0.735 & 1.165 & 6.51 \\
\hline 2 ton $\mathrm{PM} \mathrm{ha}^{-1}$ & 8.88 & 17.62 & 21.75 & 0.421 & 0.914 & 1.274 & 8.70 \\
\hline 1 ton $\mathrm{PM} \mathrm{ha}^{-1}+10 \mathrm{~kg} \mathrm{~N} \mathrm{ha}^{-1}$ & 8.38 & 18.25 & 25.00 & 0.368 & 0.999 & 1.521 & 11.89 \\
\hline 1 ton $\mathrm{PM} \mathrm{ha}^{-1}+20 \mathrm{~kg} \mathrm{~N} \mathrm{ha}^{-1}$ & 8.00 & 14.38 & 22.38 & 0.327 & 0.726 & 1.383 & 7.62 \\
\hline Inoculant & 7.50 & 13.50 & 20.25 & 0.317 & 0.673 & 1.207 & 7.95 \\
\hline LSD (5\%) & NS & 0.40 & NS & NS & 0.092 & NS & 0.52 \\
\hline \multicolumn{8}{|l|}{ Variety X Fertilizer level } \\
\hline $\operatorname{LSD}(5 \%)$ & NS & NS & NS & NS & NS & NS & NS \\
\hline $\mathrm{CV}(\%)$ & 10.2 & 10.0 & 12 & 6.7 & 8.0 & 11.3 & 17.6 \\
\hline
\end{tabular}

$\mathrm{CGR}=$ Crop growth rate. DAP= Days after planting. $\mathrm{NS}=$ Not significant. PM= Poultry manure.

\subsection{Effect on yield and yield components}

The greatest number of seeds per pod were produced by combined application of poultry manure at the rate of 1 ton ha ${ }^{-1}$ and inorganic nitrogen fertilizer at the rate of $10 \mathrm{~kg} \mathrm{~N} \mathrm{ha}^{-1}$, whereas the lowest number of seeds per pod were produced by $40 \mathrm{~kg} \mathrm{~N} \mathrm{ha}^{-1}$ and the control plot treatments (Table 3). This might be due to the combination of organic manure with inorganic nitrogen fertilizer that improved the soil chemical and physical properties for better growth and yield. Olusegun [27] found significantly greater number of seeds per pod in cowpea that were treated with combination of pig manure and inorganic nitrogen fertilizer over the single pig manure and inorganic nitrogen fertilizer and the control plots. Abayomi et al. [34] also reported that single application of inorganic nitrogen fertilizer at the higher rate depressed most of the yield components including number of pods per plant and number of seeds per pod in cowpea. Furthermore, significant differences in number of seeds per pod were observed among cowpea varieties. The greater number of seeds per pod was produced by Asontem and the lower was produced by Songotra variety. This might due to the genetic potential of each variety to bear different size of pods [29]. This result is in conformity with the work of Abayomi et al. [34] who obtained significant differences in number of seeds per pod among different cowpea genotypes. The greatest 100 seed weight was obtained by the two combined applications of poultry manure and inorganic nitrogen fertilizer treatments, whereas the lowest was obtained by the inoculant and control treatments (Table3). This might be as a result of superiority effect of integrated plant nutrient supply over a single use of organic manure or inorganic fertilizer in terms of supplying balanced nutrients to the plants. According to Olusegun [27] finding the combined application of pig manure and inorganic nitrogen fertilizer resulted in significantly greater 100 seed weight of cowpea than single application of pig manure, inorganic nitrogen fertilizer and the control plots. Similar observations made by Ayoola and Adeniyan [35]. Moreover, significant differences were observed among the cowpea varieties. Cowpea varietal differences may be due to genotypic characteristics as reported by Abayomi et al. [34] and Agyeman et al. [19].

The maximum harvest index was recorded by combined application of poultry manure at the rate of 1 ton $\mathrm{ha}^{-1}$ and inorganic nitrogen fertilizer at the rate of $10 \mathrm{~kg} \mathrm{~N} \mathrm{ha}^{-1}$, whereas the lowest harvest index was recorded by the control plots (Table 3). This might be due to the production of more number of leaves as 
observed which benefited from better interception of solar radiations for more efficient photosynthesis, this make assimilate for grain filling. This result contradicts with the result of Boateng et al. [30] who found that single application of poultry manure significantly increased the harvest index of maize than combined application of poultry manure and inorganic nitrogen fertilizer. There were no significant differences among the cowpea varieties. This result is in contrast with findings of Amoatey [28] who found significant differences in harvest index among different varieties of cowpea. The greatest grain yield was produced by combined application of poultry manure at the rate of 1 ton ha ${ }^{-1}$ and inorganic nitrogen fertilizer at the rate of $10 \mathrm{~kg} \mathrm{~N} \mathrm{ha}^{-1}$, whereas the lowest grain yield was produced by the control treatments. This might be due to integration of organic manure and inorganic nitrogen fertilizer that benefits the plants in supplying balanced nutrients and improvement in the soil physical and chemical properties. Fuchs et al. [36] reported that plant nutrients from inorganic fertilizers enhance the establishment of crops while those from mineralization of organic manure promoted yield when both fertilizers were combined. Similarly, Yoganathan et al. [12] were reported that the highest grain yield of cowpea was obtained by combined application of poultry manure and inorganic nitrogen fertilizer than single application of poultry manure and inorganic nitrogen fertilizer. Also Olusegun [27] and Adeniyan and Ojeniyi [37] made similar reports.

Table 3. Effect of treatments on grain yield and yield components of cowpea.

\begin{tabular}{|c|c|c|c|c|}
\hline Treatments & $\begin{array}{c}\begin{array}{c}\text { No. of seeds/ } \\
\text { Pod }\end{array} \\
\end{array}$ & $\begin{array}{c}100 \text { seed } \\
\text { weight }(\mathrm{g})\end{array}$ & $\begin{array}{c}\text { Harvest index } \\
(\%)\end{array}$ & $\begin{array}{c}\text { Grain yield } \\
\left(\mathrm{kg} \mathrm{ha}^{-1}\right)\end{array}$ \\
\hline \multicolumn{5}{|l|}{ Varieties } \\
\hline Asontem & 10.86 & 10.69 & 42.49 & 1356.27 \\
\hline Songotra & 7.75 & 13.98 & 40.47 & 1549.14 \\
\hline $\operatorname{LSD}(5 \%)$ & 0.56 & $\mathbf{0 . 3 0}$ & NS & NS \\
\hline \multicolumn{5}{|l|}{ Fertilizer levels } \\
\hline $0 \mathrm{~kg} \mathrm{~N} \mathrm{ha}^{-1}$ & 8.75 & 11.21 & 35.47 & 1107.06 \\
\hline $20 \mathrm{~kg} \mathrm{~N} \mathrm{ha}^{-1}$ & 9.00 & 12.15 & 40.21 & 1386.49 \\
\hline $40 \mathrm{~kg} \mathrm{~N} \mathrm{ha}^{-1}$ & 8.62 & 12.39 & 39.52 & 1349.21 \\
\hline 2 ton $\mathrm{PM} \mathrm{ha}^{-1}$ & 9.25 & 12.20 & 40.62 & 1489.84 \\
\hline 1 ton $\mathrm{PM} \mathrm{ha}{ }^{-1}+10 \mathrm{~kg} \mathrm{~N} \mathrm{ha}^{-1}$ & 10.38 & 13.54 & 51.59 & 2005.50 \\
\hline 1 ton $\mathrm{PM} \mathrm{ha}^{-1}+20 \mathrm{~kg} \mathrm{~N} \mathrm{ha}^{-1}$ & 9.75 & 12.94 & 39.26 & 1439.03 \\
\hline Inoculant & 9.38 & 11.92 & 43.67 & 1391.80 \\
\hline $\operatorname{LSD}(5 \%)$ & 1.04 & 0.55 & 0.71 & 5.37 \\
\hline \multicolumn{5}{|l|}{ Variety X Fertilizer level } \\
\hline LSD (5\%) & NS & NS & NS & NS \\
\hline $\mathrm{CV}(\%)$ & 11.1 & 4.5 & 10.9 & 14.1 \\
\hline
\end{tabular}

$\mathrm{DAP}=$ Days after planting. NS= Not significant. $\mathrm{PM}=$ Poultry manure.

\section{CONCLUSIONS}

The result showed that combined application of poultry manure at the rate of 1 ton $\mathrm{ha}^{-1}$ and inorganic nitrogen fertilizer at the rate of $10 \mathrm{~kg} \mathrm{~N}^{-1}$ were significantly increased the growth, grain yield and yield components of cowpea varieties. Moreover, application of $\mathrm{N}$ increased the growth of the cowpea varieties. Even when differences were not significant the control treatment effects were mostly numerically lower than the fertilizer and inoculation treatments. Additionally, all fertilizer and inoculation treatments produced greater grain yield than the control treatments. Asontem variety was showed significantly increased growth and higher number of seeds per pod, while Songotra variety was produced greater 100 seed weight. However, the grain yield was not significantly different among the two varieties. The interaction effects between cowpea varieties and fertilizer levels for growth parameters and grain yield and yield components were not significant. Hence, combined application of poultry manure with inorganic nitrogen fertilizer should be recognized as the most suitable way of ensuring high cowpea yield. Also, further studies should be conducted in the major and minor rainy seasons at various locations by using more varieties of cowpea to ascertain the effects.

\section{References}

[1]. Sanginga N. Role of biological nitrogen fixation in legume based cropping systems; a case study of West Africa farming systems. Plant and Soil, 252(1), 2003, 25-39.

[2]. Muimui KK. Beans Stakeholder Consultative Workshop. Common Wealth Youth Program Africa, 2010.

[3]. MoFA. Ministry of Food and Agriculture. Research and Information directorate (SRID), Report, Ghana, 2010.

[4]. ICRISAT. International Crops Research Institute for Semi-arid Tropics. Bulletin for tropical legumes, 2012.

[5]. Ofosu-Budu KG, Obeng-Ofori D, Afreh-Nuamah K, Annobill R. Effect of phospho-compost on growth and yield of cowpea (Vigna anguiculata). Ghana Journal of Agricultural Science, 40(2), 2007, 169-176.

[6]. SARI. Savanna Agricultural Research Institute. Annual Report, Ghana, 1995.

[7]. Kombiok JM, Sogbedji JM, Buah SSJ. Enhancing Soil Fertility for Cereal Crop Production through Biological Practices and the Integration of Organic and In-Organic Fertilizers in Northern Savanna Zone of Ghana. INTECH Open Access Publisher, 2012.

[8]. FAO. Food and Agricultural Organization. Fertilizer use by crop in Ghana, 39, 2005..

[9]. MoFA. Ministry of Food and Agriculture. Towards a sustainable soil fertility strategy in Ghana, Ghana, 2015. 
[10]. Akpalu M, Salaam M, Oppong-Sekyere D, Akpalu S. Farmers' Knowledge and Cultivation of Cowpea (Vigna unguiculata (L.) Verdc.) in Three Communities of Bolgatanga Municipality, Upper East Region, Ghana. British Journal of Applied Science \& Technology, 4(5), 2014, 775 .

[11]. Palm AC, Myers RJ, Nandwa SM. Combined use of organic and inorganic nutrient sources for soil fertility maintenance and replenishment. Replenishing soil fertility in Africa, 1997, 193-217.

[12]. Yoganathan R, Gunasekera H, Hariharan R. Integrated Use of Animal Manure and Inorganic Fertilizer on Growth and Yield of Vegetable Cowpea (Vigna uniquiculata). Paper presented at the Proceedings of World Academy of Science, Engineering and Technology, 2013.

[13]. Drew, E, Herridge D, Ballard, R, O’Hara G, Deaker R, Denton M, Phillips L. Inoculating legumes, a practical guide. Grains Research and Development Corporation, 2012.

[14]. Hunter R, Halverson T, Anderson R. Quality assurance for plant tissue analysis by ICP-AES Communicatio in Soil Science and Plant Analysis, 15(11), 1984, 1285-1322.

[15]. Jackson M. Soil and plant chemical analysis: New Delhi, India: Prentice Hall of India, Private Limmited, 1967.

[16]. Shortall JG, Liebhardt WC. Yield and growth of corn as affected by poultry manure. Journal of Environmental Quality, 4(2), 1975, 186-191.

[17]. Radford P. Growth analysis formulae-their use and abuse. Crop science, 7(3), 1967, 171-175.

[18]. Donald CM. Competition among crop and pasture plants. Advances in agronomy, 15, 1963, 1-118.

[19]. Agyeman K, Berchie J, Osei-Bonsu I, Fordjour J. Seed yield and agronomic performance of seven improved cowpea (Vigna unguiculata L.) varieties in Ghana. African Journal of Agricultural Research, 10(4), 2015, 215-221.

[20]. Blum A, Mayer J, Golan G. Agronomic and physiological assessments of genotypic variation for drought resistance in sorghum. Crop and Pasture Science, 40(1), 1989, 49-61.

[21]. Dart J, Islam R, Dobereiner J. Some effects of temperature and composition of the rooting medium in symbiotic nitrogen fixation in plants synthesis. Cambridge University Press, 1977, 361-383.

[22]. Verma H, Chovatia P, Sharma S, Shivran A. Growth and yield of cowpea as influenced by nitrogen and phosphorus levels on medium black soils of Gujarat. Annals of Agricultural Research, 36(4) 2015.

[23]. Bill U. Manure and soil organic matter. Pennsylvania Stat Field Crop News, 1(11) 2001

[24]. IFIA. Sustainable agriculture systems for the 21 st century. The role of mineral fertilizers. IFIA, Paris, France, 1992.

[25]. Kisetu E, Assenga S. Effects of poultry and goat manures to cowpea variety Vuli-1 grown on a highly weathered soil in Morogoro, Tanzania. Unique Res. Journal of Agricultural Science, 1(3), 2013, 028-034.

[26]. Karikari B, Arkorful E, Addy S. Growth, Nodulation and Yield Response of Cowpea to Phosphorus Fertilizer Application in Ghana. Journal of Agronomy, 14(4), 2015, 234.

[27]. Olusegun OS. Influence of NPK 15-15-15 fertilizer and pig manure on nutrient dynamics and production of cowpea, Vigna unguiculata L. Walp. American Jornal of Agronomy and Forest, 2(6), 2014, 267-273.

[28]. Amoatey HM. Genetic Studies in Some Cowpea (Vigna Unguiculata (L) Walp.) Varieties in Ghana. University of Ghana, 1987.

[29]. Futuless KN, Bake, ID. Evaluation of yield and yield attributes of some cowpea (Vigna unguiculata (L). Walp) varieties in northern Guinea Savanna. Journal of American Science, 6(8), 2010.

[30]. Boateng SA, Zickermann J, Kornahrens M. Poultry manure effect on growth and yield of maize. West African Journal of Applied Ecology, 9(1), 2006.

[31]. Addo-Quaye AA, Darkwa AA, Ampiah MKP. Performance of three cowpea (Vigna anguiculata (L) Walp) varieties in two agro ecological zones of the central region of Ghana I: dry matter production and growth analysis. ARPN Journal of Agricultural and Biological Science, 6(2), 2011, 1990-6145.

[32]. Babaji B, Yahaya R, Mahadi M, Jaliya M, Sharifai A, Kura H, Ajeigbe H. Growth attributes and pod yield of four cowpea (Vigna unguiculata (L.) Walp.) varieties as influenced by residual effect of different application rates of farmyard manure. Journal of Agricultural Science, 3(2), 2011, 165.

[33]. Taura D, Fatima M. Effects of organic and inorganic fertilizers on the vegetative and reproductive parts of some selected varieties of cowpea (Vigna unguiculata). African journal of general agriculture, 4(2), 2008, 79-86.

[34]. Abayomi Y, Ajibade T, Sammuel O, Saadudeen B. Growth and yield responses of cowpea (Vigna unguiculata (L.) Walp) genotypes to nitrogen fertilizer (NPK) application in the Southern Guinea Savanna zone of Nigeria. Asian Journal of Plant Science, 7(2), 2008, $170-176$.

[35]. Ayoola O, Adeniyan O. Influence of poultry manure and NPK fertilizer on yield and yield components of crops under different cropping systems in south west Nigeria. African Journal of Biotechnology, 5(15), 2006.

[36]. Fuchs W, Rauhe K, Wicke H. Effects of organic manure, mineral fertilizers and organo-mineral fertilizing on development and yield of cereals. Albrecht-Thaer-Arch., 14, 1970, 359-366.

[37]. Adeniyan O, Ojeniyi S. Effect of poultry manure, NPK 15-15-15 and combination of their reduced levels on maize growth and soil chemical properties. Nigerian Journal of Soil Science, 15(1), 2005, 34-41. 